\title{
Aquatic Plant Community in Porto Primavera Reservoir ${ }^{1}$
}

\author{
Avaliação da Comunidade de Plantas Aquáticas do Reservatório de Porto Primavera
}

PITELLI, R.L.C.M. ${ }^{2}$, PITELLI, R.A. ${ }^{3}$, RODRIGUES, C.J. ${ }^{4}$, and DIAS, J.H.P. ${ }^{4}$

\begin{abstract}
Aiming to identify the populations of aquatic plants present in the Porto Primavera reservoir and evaluate the behavior of Hydrilla verticillata colonization of this water body a survey was carried out in 2007 . The data was based on presence or absence, only were assessed the presence or absence of the species and the data were subjected to cluster analysis to establish differences in distribution and occurrence of populations. The community of aquatic plants showed 24 species distributed in 16 botanical families. Cyperaceae and Pontederiaceae were the most representative in terms of species richness. The submerged macrophyte Hydrilla verticillata showed the highest frequency of occurrence in the water body, showing a different behavior from the other populations of the water body. Species like Eichhornia crassipes, Eichhornia azurea, Typha dominguensis and Oxycaryum cubense also showed different behavior in relation to other populations within the community, forming large populations in lagoons and backwater areas.
\end{abstract}

Keywords: Hydrilla verticillata, reservoirs, aquatic macrophytes exotic invasive aquatic weed.

RESUMO - Com os objetivos de identificar as populações de plantas aquáticas presentes no reservatório de Porto Primavera e avaliar o comportamento de Hydrilla verticillata como colonizadora deste corpo hídrico, foi realizado um levantamento no ano de 2007. As margens do reservatório foram percorridas por embarcação motorizada, identificando-se todos os bancos de macrófitas aquáticas encontrados. Apenas foi avaliada a presença ou ausência da espécie, e os dados foram submetidos a uma análise multivariada de agrupamento, visando estabelecer diferenças de distribuição entre as populações. A comunidade de plantas aquáticas apresentou 24 espécies, distribuídas em 16 famílias botânicas, sendo Cyperaceae e Pontederiaceae as mais representativas em termos de riqueza de espécies. A macrófita submersa Hydrilla verticillata apresentou a maior frequência de ocorrência no corpo hídrico, demonstrando comportamento diferenciado das demais populações do corpo hídrico. Espécies como Eichhornia crassipes, Eichhornia azurea, Typha dominguensis e Oxycaryum cubense também mostraram comportamento diferenciado em relação às outras populações da comunidade, formando grandes populações em lagoas marginais e áreas de remanso.

Palavras-chave: Hydrilla verticillata, macrófitas aquáticas, planta aquática invasora exótica.

Recebido para publicação em 23.11.2013 e aprovado em 5.2.2014.

ECOSAFE, Agricultura e Meio Ambiente SS Ltda., Jaboticabal, São Paulo, <rlpitelli@ecosafe.agr.br>; ${ }^{3}$ UNESP, JaboticabalSP, Brasil; ${ }^{4}$ CESP, São Paulo-SP, Brasil. 


\section{INTRODUCTION}

The dynamics of aquatic plants is one of the main factors to be considered when establishing a water body management plan. Porto Primavera reservoir has had problems with aquatic weeds, mainly with Hydrilla verticillata. This plant can be found in several parts of that water body, with heavy infestations, according to reports from the CESP environment monitoring team, conducted from 2010. Due to its large flooded area, this water body is believed to present feasible conditions for a significant development of Hydrilla verticillata populations.

The first step in the management program for aquatic weeds in water reservoir is based on the botanical survey of the species present in the water body. With such information, it is possible to infer how the presence of particular species can harm the generating activities of a water body, and which techniques can avoid population growth. Martins et al. (2008) have conducted a survey on species of aquatic weeds infesting 18 reservoirs in the state of São Paulo. These authors have found 39 species belonging to 21 different botanical families. The five species most commonly found in the reservoir of Porto Primavera and Jupiá were Salvinia auriculata, Eichhornia crassipes, Cyperus sp., Pistia stratiotes and Typha latifolia (97.4; 79.5; 51.3; 46.2; and 46.2\%, respectively). The submerged plants, Ceratophyllum demersum, Egeria najas, and Egeria densa, showed values of absolute and relative frequency of 42.9 and $5.7 \%, 50.0$ and $6.7 \%$ and 60.0 and $8.0 \%$, respectively. Pivari et al. (2008) have conducted a floristic survey of aquatic macrophytes in Lake Silvana, at Vale do Rio Doce, and found 56 species of aquatic macrophytes belonging to 46 genera and distributed in 35 botanical families, where Cyperaceae and Onagraceae were the most commonly found, with six species each.

Hydrilla verticillata was found and identified for the first time in June 2005, colonizing the Porto Primavera reservoir (Anderson et al., 2005), and, subsequently, Thomaz et al. (2009) found it in the Itaipu reservoir. Since then, it has rapidly spread along the Paraná River, infesting large areas with high biomass production and causing transport, fishing, and recreation related problems.

This present study aimed to conduct a floristic survey of the main species of aquatic macrophytes in the Porto Primavera reservoir (Paraná River) in the year 2007, and analyze the current relevance of the Hydrilla verticillata population in the macrophyte community.

\section{MATERIAL AND METHODS}

The Porto Primavera reservoir was assessed for the specific composition of the existing aquatic macrophytes. The floristic survey was conducted from January to December 2007. The survey of aquatic macrophytes species that infested the site of Porto Primavera reservoir began at the Jupia dam and was extended to the city of Primavera in the state of São Paulo, Brazil.

The state power company (CESP Companhia Energética de São Paulo) provided a boat for the search and identification of all aquatic macrophytes on site. Rooted emerged plants, which develop on the banks, floating plants, and submerged aquatic macrophytes were assessed. The assessment of submerged aquatic macrophytes was made by dipping a hook to capture all plant tissue at any height of the water column, including those with the substrate.

At the Presidente Epitácio region, central part of the water body, the methodology of floristic survey was more focused on the presence of $H$. verticillata. This time, instead of following the shoreline of the reservoir, a diagonal trajectory to the direction of water flow was used for the assessment. It started from one side of the reservoir and ended on its opposite side, so that its entire width could be examined. In this trajectory, the occurrence of submerged macrophytes was assessed at each interval of $1-2 \mathrm{~km}$, by immersing a tool to capture the existing aquatic plants in the water column. Tubers on the substrates attached to the root system of these macrophytes helped confirm that they were $H$. verticillata.

Results regarding aquatic macrophyte species found in the water body were analyzed 
for frequency of occurrence, since it was not possible to quantify them. Data on the occurrence of macrophytes were subjected to cluster analysis with the intent to determine behavior differences among the existing populations of the water body.

\section{RESULTS AND DISCUSSION}

Table 1 shows the values of frequency and relative frequency of the existing aquatic macrophytes populations in Porto Primavera during 2007. The community of aquatic macrophytes in the reservoir consisted of 24 species, distributed in 16 botanical families. The largest families in terms of number of individuals were Cyperaceae and Pontederiaceae, with three species each. However, Hydrocharitaceae, with only two species, was the major family in terms of relative importance (relative frequency), followed by Pontederiaceae.

Table 1 - Frequency and relative frequency of existing aquatic macrophyte populations in the Porto Primavera reservoir in 2007

\begin{tabular}{|l|l|r|r|}
\hline \multicolumn{1}{|c|}{ Species } & Bayer Codes & F (\%) & FR (\%) \\
\hline Hydrilla verticillata & HYDVE & 41.83 & 28.07 \\
\hline Eichhornia crassipes & EICCR & 15.54 & 10.43 \\
\hline Egeria densa & EGEDE & 6.97 & 4.68 \\
\hline Pistia stratiotes & PISST & 0.40 & 0.27 \\
\hline Typha dominguensis & THYDO & 17.33 & 11.63 \\
\hline Ceratophyllum demersum & CEYDE & 2.99 & 2.01 \\
\hline Brachiaria subquadripara & BRASU & 2.59 & 1.74 \\
\hline Salvinia herzogii & SAVHE & 5.18 & 3.48 \\
\hline Oxycaryum cubense & OXYCU & 19.12 & 12.83 \\
\hline Polygonum lapathifolium & POLLA & 1.00 & 0.67 \\
\hline Ludwigia sp & LUD.SP & 2.39 & 1.60 \\
\hline Eichhornia azurea & EICAZ & 24.30 & 16.31 \\
\hline Myriophyllum aquaticum & MYRAC & 0.60 & 0.40 \\
\hline Hydrocotyle ranunculoides & HYDRA & 0.40 & 0.27 \\
\hline Rhynchospora aurea & RHCAU & 0.20 & 0.13 \\
\hline Paspalum repens & PASRE & 0.20 & 0.13 \\
\hline Eleocharis intertincta & ELOIN & 0.80 & 0.53 \\
\hline Pontederia cordata & POFCL & 0.40 & 0.27 \\
\hline Ludwigia sedoides & LUDSE & 0.20 & 0.13 \\
\hline Nitella sp. & NIT.SS & 1.39 & 0.94 \\
\hline Nymphaea odorata & NYMCO & 3.98 & 2.67 \\
\hline Nymphoides indica & NYPIN & 0.20 & 0.13 \\
\hline Potamogeton pectinatus & POTAPE & 0.20 & 0.13 \\
\hline Ipomoea sp. & IPO.SS & 0.80 & 0.53 \\
\hline
\end{tabular}

Hydrilla verticillata was the most commonly found macrophyte in this period of survey, found in over $40 \%$ of the sampled sites. Subsequently, E. azurea, O. cubense and Typha dominguensis were also found. Plant community assessments concentrated in shallower regions near the shoreline of the water body, where further development of populations of aquatic macrophytes occurs. Therefore, in these shallower sites, as well as in the adjacent ponds, large banks of $H$. verticillata dominating the water surface, as well as populations of $T$. dominguensis, $E$. azurea, E. crassipes, and $O$. cubense, that colonize the shallow and shoreline areas of this backwater.

Among the submerged macrophytes, C. demersum was found in only one region of the reservoir, near the city of Presidente Epitácio, while E. densa was found in a few locations near the Primavera dam. However, both showed low frequency of occurrence and very small populations. The other species had low population density and were found colonizing the marginal region of islands, or even floating islands, of $T$. dominguensis. Other species were represented by one individual only, which, at the end of the survey sequence period, were hardly seen, probably due to competition with other species, for instance, Sagittaria montevidensis, Hydrocleis nymphoides, Limnobium spongiae, Rynchospora aurea and Chara sp. algae.

From 1998 to 2000, Martins et al. (2009) conducted a floristic survey of aquatic plants from the Porto Primavera reservoir before its final stage of filling, in 253-257 $\mathrm{m}$ of altitude. The authors found 18 species of aquatic macrophytes, distributed in 10 botanical families - lower than the amount presented in this work. At that time, the floating macrophytes were the main colonizers of this water body. Populations of E. crassipes, E. azurea, $P$. stratiotes and S. auriculata had relative frequencies of $36,17,14$ and $13 \%$, respectively. These results agree with those found by Tanaka et al. (2002), which, among 17 species identified, floating macrophytes, such as E. crassipes, P. stratiotes, S. molesta and $S$. minima, were found more frequently in Porto Primavera. A relevant observation is that, of all the major colonizing species in 
the reservoir, at different times, none had submerging habits.

Figures 1 and 2 show the dendrograms of dissimilarity related to the cluster analysis of aquatic macrophyte populations, with two clustering techniques: completelinkage and Ward method. In Figure 1, it is possible to observe the formation of a group with distinct behavior, which includes the populations of $H$. verticillata, E. azurea, E. crassipes, $O$. cubense and T. dominguensis.

The behavior of these populations is most evident when using the completelinkage method of clustering, where we can note the formation of a group with distinct behavior consisting exclusively of $H$. verticillata. In this second clustering approach, populations of T. dominguensis, E. crassipes, E. azurea and $O$. cubense form clusters of distinct behavior in relation to others. These species had high population density in adjacent lagoons and backwaters, besides colonizing the shoreline of natural lagoons and impounded lakes. A fourth behavior group can be found where representative populations show very small differences in behavior in relation to the colonization of the water body. Within this group, important species can be found as colonizers of other water bodies, such as Salvinia herzoggii, C. demersum, E. densa and Brachiaria subquadripara. Observe that, in the Ward method, these species are grouped into distinct cluster, showing their different behavior in relation to the other populations of this group. This demonstrates that such technique is more suitable to examine the behavior differences between aquatic macrophyte populations in the Porto Primavera reservoir conditions. The clustering method was able to show which population of $H$. verticillata was the most dominant in relation to other populations within the community. This dominance is expressed mainly by its greater spatial distribution.

Results indicate that $H$. verticillata is the major macrophyte in the Porto Primavera reservoir. This submerged macrophyte was initially mistaken for Egeria najas. Hydrilla verticillata is a relatively new species in Brazil, found in Porto Primavera for the first time in 2006 by Anderson et al. (2005).
Hydrilla is a genus of aquatic plants native from Asia (Cook, 1985) and it can be a problematic submerged weed in many tropical and subtropical regions around the world (Cook \& Lüönd, 1982). Its reported ability to colonize and grow essentially in monospecific colonization, replacing the native flora in a variety of aquatic habitats, cause many problems for the management of aquatic environments. This macrophyte is difficult to control because they produce several underground tubers, which provide a source of vegetative propagules for the emergence of new plants, since the mother plant was killed by chemical, physical or biological methods (Sutton et al., 1992).

$H$. verticillata dioica produces its tubers in response to short photoperiod, with a critical photoperiod of 13 hours or less (Van et al. 1999). Haller et al. (1976) reported that dioic $H$. verticillata in North Florida, United States, produces tubers from October to April and they germinate in the following May.

This submerged macrophytes can reproduce through fragments, tubers, axilary turions, seeds, stolons, and rhizomes. Tubers and shoots are specially adapted to survive in unfavorable conditions (Pieterse, 1981). Harlan et al. (1985) reported densities of 2001228 tubers $\mathrm{m}^{-2}$ of monoic $H$. verticillata in three lakes in the state of North Carolina, without any seasonal trend. The authors also found that, typically, 93 to $100 \%$ of the tubers are presented in the first $12 \mathrm{~cm}$ of hydrosoil.

Hydrilla verticillata was introduced in Florida (USA) in the late 50's and in 40 years spread over 280 water bodies, covering more than 56,600 hectares (Langeland, 1996). Between 1992 and 1994, infestations doubled in size from 20,000 to 40,000 hectares, requiring nearly 14 million dollars for their management (Schardt, 1997).

This plant is able to grow $2.5 \mathrm{~cm}$ per day and form dense monotypic stands, reducing local biodiversity and native vegetation (Langeland, 1996; Van etal., 1999). Changes in the physical properties of water, including flow rate, conductivity, turbidity and dissolved oxygen has been associated with the presence of $H$. verticillata (Langeland, 1996, Van et al., 1999). 
Ward`s method

Euclidean distances

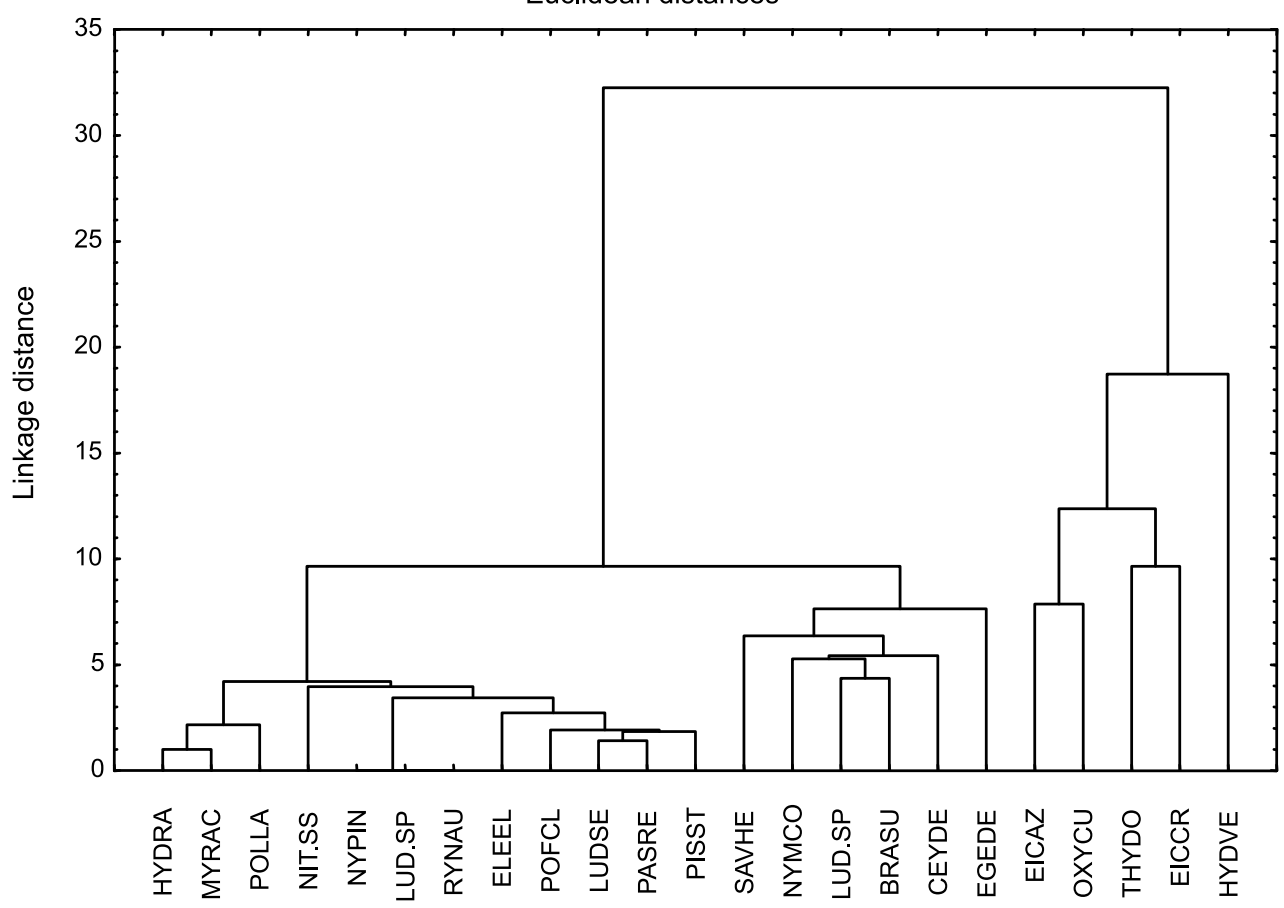

Figure 1 - Survey data cluster analysis from aquatic macrophyte presence in Porto Primavera reservoir in 2007, using the Ward method.

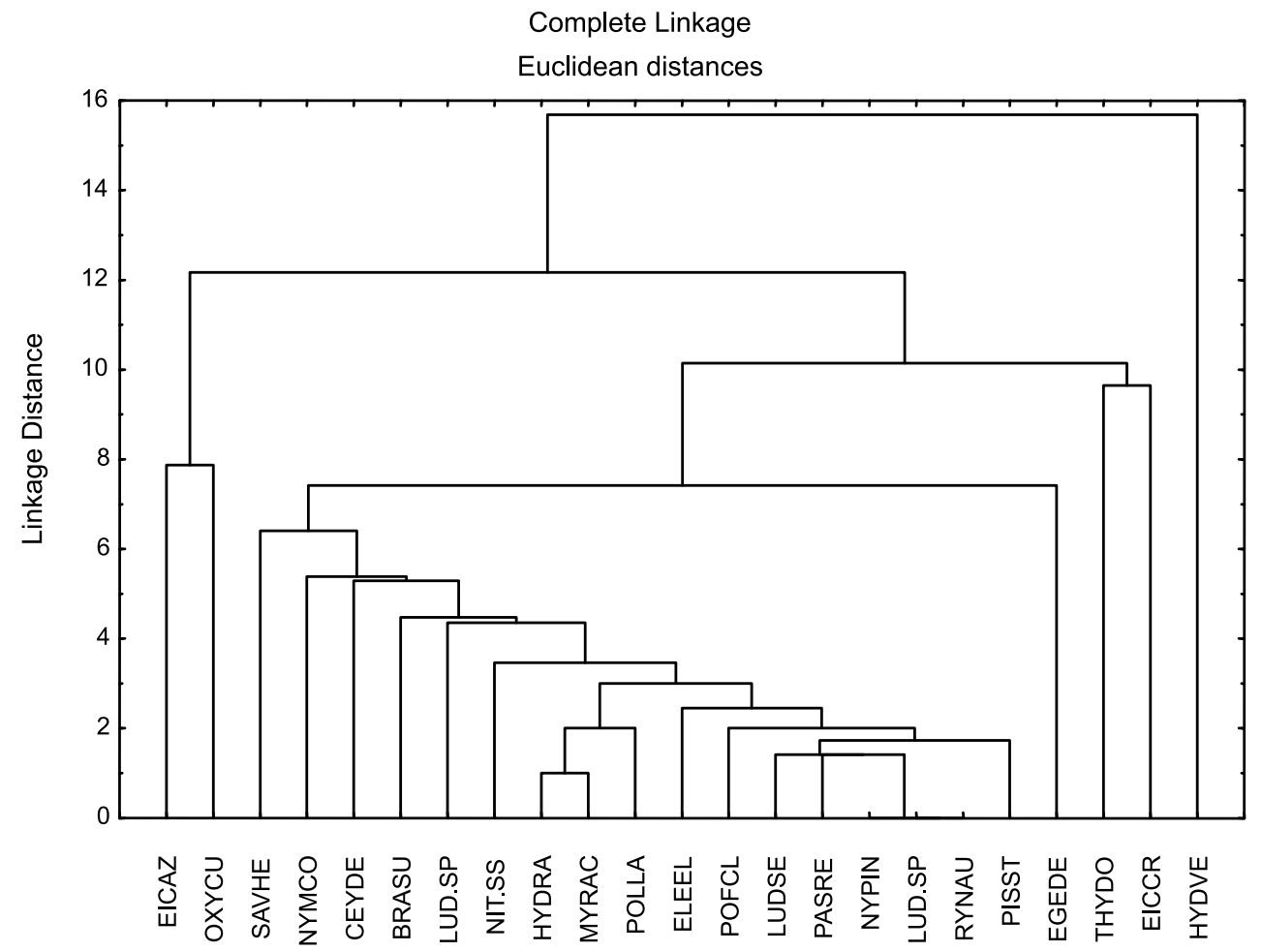

Figure 2 - Survey data cluster analysis from aquatic macrophyte presence in Porto Primavera reservoir in 2007, using completelinkage as the clustering technique. 
Bianchini, Jr. et al (2010) studied the growth of $H$. verticillata from the Porto Primavera reservoir in laboratory conditions. The plant had doubled it biomass in 19.8 days and in 2.5 to 11 days when grown from tubers. Souza et al. (2010) studied the behavior of submerged aquatic plants in the Parana river, in relation to the hydrological regime, and observed that $H$. erticillata did not grow well in ponds, possibly due to the high proportion of organic matter in the sediment. In lakes, E. najas reached $628 \pm 82 \mathrm{~g} \mathrm{~S} \mathrm{~m}^{-2}$ biomass, while in the river channel $H$. verticillata produced $1415 \pm 255 \mathrm{~g} \mathrm{MS} \mathrm{m}^{-2}$.

Currently, Hydrilla verticillata tubers were found in the reservoir of Nova Avanhandava (Tietê River), which indicates a new spread of this type of weed (Pitelli et al. 2012).

The present study has shown that $H$. verticillata has found ideal conditions for a profuse population development in the Porto Primavera reservoir. Despite the great taxonomic diversity of the community, this plant has much superior relevance when compared with other populations, even with submerged plants. It is of paramount importance to study the behavior of this submerged macrophyte to establishing appropriate management plans for this new aquatic invader.

\section{LITERATURE CITED}

ANDERSON, L. W. J. et al. First Hydrilla found in Brazil: Implications and further dispersal and likely impacts. In: AQUATIC PKANT MANAGEMENT SOCIETY ANNUAL MEETING, 25., San Antonio Texas, 2005. Abstracts... San Antonio Texas, 2005. p. 11-13.

BIANCHINI JR., I. et al. Growth of Hydrilla verticillata (L.f.) Royle under controlled conditions. Hydrobiologia, v. 644, n. 1, p. 301-312, 2010.

COOK, C. D. K. Range extensions of aquatic vascular plant species. J. Aquat. Plant Manag., v. 23, n. 1, p. 1-6, 1985.

COOK, C. D. K.; LÜÖND, R. A revision of the genus Hydrilla. Aquat. Bot., v. 13, p. 485-504, 1982.

Planta Daninha, Viçosa-MG, v. 32, n. 3, p. 467-473, 2014
HALLER, W. T.; MILLER, J. L.; GARRARD, L. A. Seasonal production and germination of hydrilla vegetative propagules. J. Aquat. Plant Manag., v. 14, n. 1, p. 26-28, 1976.

HARLAN, S. M.; DAVIS, G. J.; PESACRETA, G. J. Hydrilla in three North Carolina lakes. J. Aquat. Plant Manag., v. 23, n. 1, p. 68-71, 1985.

LANGELAND, K. A. Hydrilla verticillata (L.f.) Royle (Hydrocharitaceae), "The perfect aquatic weed". Castanea, v. 61, p. 293-304, 1996.

MARTINS, D. et al. Caracterização da comunidade de plantas aquáticas de dezoito reservatórios pertencentes a cinco bacias hidrográficas do estado de São Paulo.

Planta Daninha, v. 26, n. 1, p. 17-32, 2008.

MARTINS, D. et al. Levantamento da infestação de plantas aquáticas em Porto Primavera antes do enchimento final do reservatório. Planta Daninha, v. 27, p. 879-886, 2009. (Número Especial)

PIETERSE, A. H. Hydrilla verticillata - a review. Abstr. Trop. Agric., v. 7, n. 1, p. 9-34, 1981.

PITELLI, R. L. C. M. et al. Plantas aquáticas do reservatório de Nova Avanhandava. Botucatu: FEPAF, 2012. 95 p.

PIVARI, M. O.; POTT, V. J.; POTT, A. Macrófitas aquáticas de ilhas flutuantes (baceiros) nas sub-regiões do Abobral e Miranda, Pantanal, MS, Brasil. Acta Bot. Bras., v. 22, n. 2, p. 563-571, 2008.

SCHARDT, J. D. Maintenance and control. In: SIMBERLOFF, D.; SCHMITZ, D. C.; BROWN, T. C. (Ed.). Strangers in Paradise. Covelo: Island Press, 1997.p. 229-243,

SUTTON, D. et al. Growth of dioecious and monoecious Hydrilla from single tubers. J. Aquat. Plant Manag., v. 30, n. 1, p. 15-20, 1992.

SOUZA, W. T. Z.; THOMAZ, S. M.; MURPHY, K. J. Response of native Egeria najas Planch and invasive Hydrilla verticillata (L.f.) Royle to altered hydroecological regime in a subtropical river. Aquat. Bot., v. 92, n. 1, p. 40-48, 2010.

TANAKA, R. H. et al. Ocorrência de plantas aquáticas nos reservatórios da Companhia Energética de São Paulo. Planta Daninha, v. 20, p. 101-111, 2002. (Número Especial) 
THOMAZ, S. M. et al. Temporal and spacial patterns of aquatic macropnhyte diversity in upper Parana River floodplain. Braz. J. Biol., v.69, n.2, p.617-625, 2009.
VAN, T. K.; WHEELER, G. S.; CENTER, T. D.

Competition between Hydrilla verticillata and Vallisneria americana as influenced by soil fertility. Aquat. Bot., v. 62, n. 4, p. 225-233, 1999. 